\title{
Brazing Operation for Aluminium Semi-Products by Heat Treatment
}

Ján Bezecný, Andrej Dubec, Mariana Janeková

University of Alexander Dubček in Trenčín. Faculty of Industrial Technologies. Department of Materials Engineering. I. Krasku 491/30. 02001 Púchov. Slovakia. E-mail: jan.bezecny@fpt.tnuni.sk, andrej.dubec@gmail.com, mariana.janekova@fpt.tnuni.sk

\begin{abstract}
Nowadays, there is an effort to increase the economic effectiveness, including manual work, from the aspect of the modernization of production technologies. The brazing operation is one of the operations requiring skills and experience and therefore, the paper deals with modern brazing technology of aluminium alloy semi-products which are heated only in the electric furnaces. Application of heat can lead to the formation of the perfect join of semi-products based on such materials as A 3004 and AA 4045. A thin layer called Clad is deposited on one component of the AA $\mathbf{4 0 4 5}$ material while the mentioned thin layer is molten to the prescribed temperature in the furnace but the most important fact is that there is not occurrence of melting in relation to the base material. After cooling, Clad creates a perfect metallurgical join between the joined surfaces. The resulting microstructure corresponds to silumin alloy. The transition between silumin alloy and aluminium matrixes of the component is continuous and without any defects in the form of discontinuities or pores and this fact was confirmed by the evaluation of the microstructure. This technology is used in the production of battery coolers in electric hybrid cars. Tightness of brazed join is controlled by pressure and helium tests. Analysed cooler was suitable from the aspect of the performed testing procedures.
\end{abstract}

Keywords: cooler, aluminum alloys, silumin, brazing.

\section{References}

[1] KLYSZEWSKI. et al. (2014). New rolled aluminium alloy products for the automotive, In: Archives or metallurgy and materials, vol. 59, p. 393-396, issue 1, ISSN (Print) 1733-3490

[2] MARIYAM JAMEELAH GHAZALI. (2011). Effects of Dry Sliding Wear of Wrought Al-Alloys on Mechanical Mixed Layers (MML), In: Recent Trends in Processing and Degradation of Aluminium Alloys. ISBN: 978- 953307-734-5, InTech, DOI: 10.5772/20480

[3] QIN. et al. (2011). Study on the composite interface of 4045/3004/4045 Aluminium alloy Ingot, In: Advanced materials research, vols. 396-398, p. 213-216, DOI: 10.4028/www.scientific.net/AMR. 396-398.213

[4] MUNDT. et al. (1994). Introduction to Brazing of Aluminium Alloys, In: TALAT Lecture 4601 European Aluminium Association, Brussels, resource ID: 2237

[5] ARNOLD. et al. (2009). Exploring different brazing and soldering methods, In: Welding Journal, vol. 88, issue 4, p. 5051, ISSN 00432296

[6] TURRIFF. et al. (2010). Diffusional solidification phenomena in clad aluminum automotive braze sheet, In: Acta materialia, vol. 58, issue 4, p. 1332-1341, ISSN 13596454

[7] TIMSIT., JANEWAY. (2011). A Novel Brazing Technique for Aluminum, In: Journal of Materials Research, vol. 8, issue 11, p. 2749-2752, DOI: http://dx.doi.org/10.1557/JMR.1993.2749

[8] Internal documents of company HVCC

[9] TIERCE. et al. (2007). Corrosion behaviour of brazed multilayer material AA4343/AA3003/AA4343: Influence of coolant parameters, In: Corrosion Science, 2007, vol. 49 ( $\left.\mathrm{N}^{\circ} 12\right)$, p. 4581-4593. ISSN 0010-938X

[10] MICHNA, Š. a spol. (2005). ENCYKLOPÉDIA HLINÍKA. Adin, s. r. o., Prešov, ISBN 80-89041-88-4 